\title{
Research on Professional Ethics of Young Teachers in Private Universities of China
}

\author{
Zhenpeng Zhao \\ School of Art and Design \\ Huanghe Science and Technology College \\ Zhengzhou, China, 450006
}

\begin{abstract}
It is a must that the construction of professional ethics of young teachers should be regarded in private universities, currently there are a few problems related to the professional ethics of young teachers to be solved for the private universities. The main reasons for the phenomena not only include social factors but also factors of private universities and young teachers themselves. In order for the construction of young teachers, five mechanisms, namely guidance, training, evaluation, incentive and supervision can be created and carried out in private universities.
\end{abstract}

Keywords-private universities; young teachers; construction of professional ethics

\section{INTRODUCTION}

Professional ethics refers to the morality concept, moral sentiments, moral conduct and moral will, which are gradually formed by teachers in education and are the codes of conducts and essential qualities that they should follow in education. Education is the foundation for national development in the long run, teachers are foundation for the development of education, and professional ethics is the foundation of the quality of teachers. In recent years, with the full support to the higher education in the country, the enrollment scale in colleges and universities is enlarging continuously, and team of teachers is expanding as well, each year a large number of young teachers are pushed to the post of education, responsible teaching and management in colleges and universities. This situation is much more obvious in private colleges and universities, statistics show, young teachers aged 35 or less account for $50 \%$ or more among teachers in private universities and the young teachers have account for about $80 \%$ in some schools or colleges. Young teachers, who are increasingly becoming the main force in teaching teams of private universities, are closely related to the sustainable development of private universities, and even to the mission of higher education. Therefore, how to strengthen the construction of professional ethics of young teachers has become a problem that more attentions should be paid by private universities.

\section{IMPORTANCE TO INTENSIFY THE CONSTRUCTION OF Professional ETHICS OF Young TEACHERS IN PRIVATE UNIVERSITIES}

\section{A. The Necessity to Promote the Scientific Development of Private Universities}

Good professional ethics is the key to drive the construction of and promote the formation of excellent school spirit, based on which, the universities may develop fast and well. Young teachers are the main body of teachers in private universities and the decisive forces for the sustainable development of the universities. The professional ethics of young teachers determine whether the private universities can make a healthy and sustainable develop.

\section{B. The Inevitable Choice to Carry Out the Sacred Duties of Higher Education}

The teacher is the engineer of the human soul, the disseminator of scientific knowledge and the guide to the upgrowth of students. The professional ethics of teachers is directly related to the healthy development of students. In private, young teachers, who are similar to students in age and active in thought, are easy in an imitation by students, and their charisma, knowledge and styles will directly influence the formation of ethical behaviors of students.

\section{The Only Way to Advance the Healthy Development of Young Teachers}

Good professional ethics that teachers own can it clear for the teachers to know the positions and roles of their own in the society, which may enhance the senses of responsibilities for work. Assume that a young teacher pays little attentions to the professional ethics of his or her own, inactive to work, it will be difficult for him or her to establish a lofty image of teacher and far to be a qualified knowledge disseminator, more unlikely to promote social changes in mental attitude, as a result, the teacher will be rejected by universities and the society.

\section{Status QuO OF PROFESSIONAL ETHICS OF Young TEACHERS IN PRIVATE UNIVERSITIES}

At present, as a whole the professional ethics of young teachers in private universities healthy, yet there are still 
deficiencies existing in the professional ethics of some teachers, mainly including:

\section{A. Poor Political Quality}

In private universities, some young teachers have not received or learned systematically theories of higher education, in the lack the basic knowledge of professional ethics and strict vocational training. Some even are filled with individualism, hedonism and money worship in thought, whose evaluation criteria on the value are floating, vague in right or wrong.

\section{B. Low Identity to Profession}

Some just take the educational work as a means of livelihood instead of "being engineers of the human soul" as a result, they pay no attentions to the research and innovation of educational thought, teaching contents, methods and modes, resting on current situation without plans for the future; some are half-hearted, making no adequate lesson preparation; repeat what the textbook says, focus only on the number of hours but not on the teaching quality; some are unfixed in thought, keen on job hopping or part-time jobs, the full energy is given to anything but the teaching, ignoring the duties and responsibilities of their own.

\section{Weakened Thought in Education}

Some of young teachers in private universities are satisfied only at the class teaching, the completion of teaching tasks, but giving little attentions to the moral education of students, and owning an one-side thought that the responsibility of a teachers is to teach but not to educate students. Due to the lack of communications between teachers and students, it is difficult to grasp the thoughts of students, as well as hot issues and difficulties, thus it will be unable to made targeted education on the students.

\section{Lack of Awareness of Scientific Research}

Young teachers in private universities are in the lack of awareness of scientific research, many are too busy with knowledge transmission and have no time for scientific research, meanwhile, some know little of the significance of the scientific research, inactive in scientific research and teaching research, as a result, the scientific research often become a negative selection for title promotion.

\section{E. Weak Awareness of Being Models}

Some hold weak awareness of being models, lack of self dignity, self respect and self love, hard to act as models; some are out of orders, coming late or leaving early and sloppily dressed; some belittle each other, disregarding other workmates before students intentionally or unintentionally; some even let off steam in class to the society, regardless of the influences of what they say to learners.

\section{FACTORS INFLUENCING THE CONSTRUCTION OF Professional ETHICS OF Young TEACHERS IN PRIVATE UNIVERSITIES}

\section{A. Social Factors}

At present, China is in a stage of social reform and transformation, where many traditional moral concepts are impacted, new changes have occurred in the whole social morals, which bring confusions and puzzles to the public. Some unhealthy, uncivilized or unethical atmospheres are also impacting the campus. Traditional values of teachers have been challenged and increasingly diversified, and even some adverse tendencies have appeared.

\section{B. Factors of Universities}

The construction of professional ethics is a systematic project, for which a standardized and scientific management system should be established in universities. However, in the private universities, some tend to focus only on the construction of hardware, ignoring that of professional ethics.

1) Imperfect training mechanism: At present, most private universities are in a stage of rapid expansion, and more attentions are paid to employment of teachers but not to training as training of professional ethics, as a result the so called training of professional ethics becomes a mere formality mostly in private universities. Though some rules and systems concerning the construction of professional ethics are establish in some universities, yet most go off the real life or are difficult for operation.

2) Irrational evaluation mechanism: At present, in most private the evaluation on professional ethics is also a mere formality, empty in content. The professional ethics is not taken as become an important base for evaluation on teachers. In case of the title promotion or pay adjustment, hardware as scientific research and number of hours are mostly considered by the universities, yet the evaluation on professional ethics is just quantified, guided by this rules, the professional ethics of young teachers will be inevitably weakened.

3) Unclear incentive mechanism: At present, there are few incentives to young teachers in some private universities, due to the characteristics of teachers in private universities, the teachers with high professional titles and high level are mostly those who retire from other colleges or universities, but young teachers have low titles and weak capabilities in teaching and research. Therefore, during the evaluation and selections such as excellent teachers, advanced workers, etc. it is difficult for young teachers to be awarded, this incentive mechanism brings few incentives to young teachers.

4) Imperfect security mechanism: Due to the restriction by some policies, the wages and benefits of teachers in private universities are falling behind that in public institutions, especially for the young teachers, who have little experience, lower wages, but high economic pressure and lower acceptance by the society.. 


\section{Individual Factors}

In addition to the social environment and the internal environment of private universities which impact the construction of professional ethics of young teachers, another important point is the teachers themselves. Young teachers in private are inactive in improving the professional ethics of their own and are not aware of the importance and urgency of strengthening the professional ethics from the special historical mission that they bear. They have no a sacred sense of being teachers with honors and responsibilities and unable to regulate themselves strictly. Besides the psychological imbalance resulted from the higher differences in social positions and benefits between teachers in private universities and persons in other trades and teachers in public institutions, all cause the failure of young teachers to improve the professional ethics of their own.

\section{Measures to StREngthen the CONSTRUCTION OF Professional ETHICS OF Young TEACHES IN PRIVATE UNIVERSITIES}

\section{A. Establish Correct Guiding Mechanisms}

In order for the construction of professional ethics of young teachers in private universities, first of all, establish correct guiding mechanisms, which include two aspects: first, policy-oriented mechanism. Private universities should establish and improve rules and systems to promote the construction of professional ethics, and drive the reforms of teaching management, scientific research management and distribution system so as to create an institutional environment and good atmosphere for education, correcting academic atmosphere and regulating academic behaviors. II. Public opinions-guided mechanism: Private universities should call on all levels of competent authorities of education and the societies through various channels to change the discrimination against private universities, and further publicize the social status and historical merits of private universities, show the styles and images of teachers in private universities teachers in order to enhance the senses of glory, responsibility and mission of the teachers. Inspire the enthusiasm of young teachers to make full contributions to teaching and private education, and form an atmosphere of favorable professional ethics and respect to teachers and education

\section{B. Establish Perfect Training Mechanism}

To strengthen the training of young teachers in professional ethics is an important part in the construction of professional ethics of young teachers in private universities, Private universities should change and abandon the misconceptions of ignoring teachers' training to save schooling costs. During the training by private universities, first, the teachers shall be trained in professional ethics, and young teachers in private universities should have the correct professional ideals and noble professional ethics. Second, train young teachers in business, guide them to develop through the combination of teaching and research, which must be carried out through training through the forms as follows: First, carry out pre-job training for young teachers and well control the admission, the newly employed young teaches should be trained in professional ethics, carry out strict examination, and take the grasping or mastery of professional ethics as an important base for jobs; Second, establish job training for teachers, regular job training should be carried out by private universities, during the training, some of excellent young teachers will be dispatched to other universities to learn advanced experience, meanwhile, experts from other universities will be invited to instruct the development of young teachers so as to enhance the sense of professional responsibilities of teachers.

\section{Establish Rational Evaluation Mechanisms}

The scientific evaluation mechanism plays an important role in protecting the continuous improvement of professional ethics of young teachers, therefore, in accordance with relevant policies, private universities should establish scientific professional ethics evaluation systems. During the evaluation on teachers, the indicators for evaluating the professional ethics of teaches should be specified and quantified, and professional ethic, teaching attitude, effect of education shall be emphasized, setting up four levels as excellent, good, pass, fail. The evaluation process shall be just, fair and open, and the results will be published, rewarding the excellent and punishing the worst, only through this way can the professional ethics of teachers especially the young teachers be improved.

\section{Establish Efficient Incentive Mechanisms}

In order to promote the construction of professional ethics of young teachers, private universities must establish an effective incentive mechanism, which can be started with the following: first, attach great importance to the emotional incentive mechanism. At the beginning of the work, emotional incentives are applicable for young teaches. School leaders should grant respect, understanding, care, trust to young teachers who shall be instructed in politics and cared in life, be offered chances for work in order for senses of accomplishment. Second, establish a fair incentive mechanism. As a social person, young teachers will not only compare themselves with other teachers of the universities of their own, but also with those in other trades. Through comparison, the sense of unfairness may cause some young teachers be depressed, on the one hand it will affect the work of enthusiasm and the teaching quality; On the other hand, it may bring resignation, or job hopping, affecting the normal operation of the teaching order and the construction of teachers' teams. Third, establish a model incentive mechanism, through the evaluation and selection of advanced models, excellent teachers who carefully perform obligations in professional ethics will be awarded outstanding teachers, advanced education workers and other honorary titles, and be praised and reported in public so as to create a good atmosphere of incentives via public opinion.

\section{E. Establish Perfect Supervision Mechanism}

The supervision mechanism plays a role of supervision and restriction in the 'professional ethics of teaches, so it needs to establish perfect supervision mechanism in order for the better effect of professional ethics of teachers in private universities. Sound supervision mechanism is shown as follows: first, 
introduce the construction of professional ethics to the teachers evaluation system, and take teachers' quality of thought and politics and moral quality be prerequisites for all evaluations, and take punishment measures for those who are worst in professional ethics. Second, create scientific and complete professional ethics files, and take performances of professional ethics as primary references for teachers' title evaluation, promotion, salary increase, training and excellence selection, those who are unqualified in professional ethics will be immediately refused in teaching employment, promotion and so on. Third, build a supervision system for the construction of professional ethics, private universities may establish a multilevel professional ethics supervision system through leaders, teachers, students and information network. According to the leader's attendance to lectures, mutual evaluation between teachers, evaluation by teaching and research offices and students' reviews, etc., the universities may grasp the professional ethics of each teacher in time and solve any problems found in teachers in time.

\section{CONCLUSION}

The construction of professional ethics of young teachers in private universities is an arduous and complicated systematic project, which should be much regarded, due to the real situations and urgency, it has to depend on the joint efforts of schools, teachers and students, meanwhile, the construction of professional ethics of young teachers shall be guaranteed in law and system for real implementation. Only the selfdiscipline is combined with heteronomy can the construction of professional ethics be carried out and provide qualified talents for the high-level and full development of the country and the nation..

\section{REFERENCES}

[1] Zeng Jiezhen, Lack and Reconstruction of Current Teachers' Code of Morality in China [J]. Journal of South China Normal University (Social Science Edition), 2003,06:86-90+151

[2] Cao Yunan, Chang Xiaoyong, Comparative Research and Enlightenment of Professional Ethics Education at Home and Abroad [J].Vocational and Technical Education, 2002,v.23;No.v.2319:61-64.

[3] Wang Ying, Experience and Enlightenment of Foreign Professional Ethics Education [J].Heilongjiang Research on Higher Education, 2009,No.18812:75-77.

[4] Wang Xiaoli, Lu Naigui, Research-Based Self-Examination and Thought of Contemporary Morality of Teachers: Comparison with Foreign Morality in Education [J].Studies in Foreign Education, 2011,v.38;No.25206:79-84.

[5] Zhang Guichun, Experience and Enlightenment of Construction of Professional Ethics of Foreign Teachers [J].Education Science, 2001, (2). 